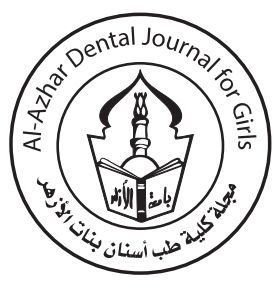

\title{
Efficacy of Apple Vinegar as Final Irrigating Solution in Removing Smear Layer Using XP-Endo Finisher File
}

\author{
Menna E. Abdelghany ${ }^{1 *}$, Wael H. Kamel ${ }^{2}$, Hagar A. Bastawy ${ }^{3}$
}

Codex : 13/2001

azhardentj@azhar.edu.eg

http://adjg.journals.ekb.eg

DOI: $10.21608 /$ adjg.2019.7841.1117

\begin{abstract}
Purpose: This study assessed the efficacy of Apple vinegar as final irrigating solution in removing smear layer using XP-Endo Finisher File by scanning microscope. Material and Methods: Fifty single rooted lower premolars were selected and prepared using Universal ProTaper rotary files. Samples were divided into two main groups (I,II) regarding the final rinse used (20 samples each) and control group (10 samples): Group I: rinsed with 17\% EDTA, Group II: rinsed with Apple vinegar and Control group: irrigated with sterile saline. Each group was subdivided into two subgroups $(A, B)$ regarding the agitation file. Subgroup A: Conventional irrigation, Subgroup B: agitated with XP Endo Finisher. Samples were grooved longitudinally and smear layer was assessed. Results: no statistically significant difference in the median scores of smear layer produced by $17 \%$ EDTA and Apple Vinegar at coronal, middle and apical root levels when conventional irrigation or XP Endo Finisher were used. There was a significant difference between two irrigating techniques at apical level when $17 \%$ EDTA used as final rinse, where XP Endo Finisher showed statistically significant lower median score $(\mathrm{P} \leq 0.05)$. Conclusions: Apple vinegar presented similar smear layer removal efficiency from intraradicular dentin compared to 17\% EDTA when used as final rinse. XP-Endo Finisher is a successful agitation system for removal of smear layer from intraradicular dentin.
\end{abstract}

\section{INTRODUCTION} remnants, microorganisms and microbial toxins, which could be achieved through chemomechanical debridement. During chemomechanical
The success of root canal treatment depends on removing pulp
Irrigation,

apple vinegar, agitation

techniques,

$X P$ endo finisher file
- Paper extracted from Master thesis titled "Efficacy of Apple vinegar as Final Irrigating Solution in Removing Smear Layer Using XP-Endo Finisher File".

1. Demonstrator of Endodontics, Endodontic Department, Faculty of Dental Medicine for Girls, Al-Azhar University.

2. Professor and Head of Endodontic Department, Faculty of Dental Medicine for Girls, Al-Azhar University.

3. Assistant Professor of Endodontics, Department of Endodontics, Faculty of Dentistry, King Abdulaziz University (KAU), Jeddah, Saudi Arabia and Endodontic Department, Faculty of Dental Medicine for Girls, Al-Azhar University, Cairo, Egypt.

* Corresponding author Email: menahelsayed@gmail.com 
preparation, debris accumulates on the wall of the canal creating an amorphous layer ${ }^{(1)}$.

The most popular irrigating solution is $\mathrm{NaOCl}$ due to its efficacy of tissue dissolution and antimicrobial activity. Even though these excellent properties, its capacity in removing the organic part of the smear layer has been found to be lacking ${ }^{(2)}$. Chelating agents are efficient in removing the inorganic part of the smear layer. The most common chelating solution is EDTA ${ }^{(3)}$.

Natural irrigants such as apple vinegar have been introduced to minimize the harmful effect of EDTA on dentin and periapical tissues. Using of apple vinegar as irrigant in the chemomechanical process has been proposed due to its promising results that are similar to EDTA ${ }^{(4)}$. It has high biocompatibility due to containing high concentration of malic acid ${ }^{(5)}$. Several studies evaluated the effect of apple vinegar on the endodontic microbes and the periapical tissue ${ }^{(6-8)}$. Apple vinegar is efficient chelating agent with bactericidal effect on microorganisms ${ }^{(9,10)}$.

Several studies evaluated the efficacy of apple vinegar on removing smear layer and they concluded that apple vinegar was more effective when used for one minute as final rinse in removing smear layer without affecting the calcium content of intraradicular dentin compared to $17 \%$ EDTA $^{(11-14)}$.

Irrigation techniques have been enhanced the effect of irrigating solutions inside the root canal ${ }^{(15)}$. Recently, a new nickel-titanium rotary finishing file, the XP-Endo Finisher file (FKG Dentaire SA, La Chaux-de-Fonds, Switzerland), was introduced to improve cleaning of the root canal ${ }^{(16)}$.

The basic principles of the XP-endo Finisher file are their shape-memory of NiTi alloy. They are straight at room temperature in $\mathrm{M}$ - phase. When they are put in the canal at body temperature, their shape will be changed depend on their molecular memory to the A- phase. This A - phase makes the files reach difficult areas to be cleaned by standard instrument ${ }^{(17)}$.
Evaluation of the power of XP-endo Finisher files after chemomechanical preparation in cleaning the coronal, middle and apical third. These resulted that using XP-endo Finisher after chemomechanical preparation effectively cleaned canal walls and removed smear layer ${ }^{(18,19)}$. Other studies compared the effect of XP-endo Finisher files and other agitation techniques. They found that agitation improve the cleaning of root canal wall especially at the apical level ${ }^{(20-24)}$. This study was evaluated the efficacy of Apple vinegar on removing smear layer using XP Endo-finisher file and comparing its results with a well-established one.

\section{MATERIAL AND METHODS}

\section{Teeth selection and root canal preparation:}

Fifty extracted single rooted lower premolars with single canal were selected and rinsed under water to eliminate the debris. Tooth was decapitated at the cemento-enamel junction under cooling and the root length was $14 \mathrm{~mm}$. Working length was measured by subtracting $1 \mathrm{~mm}$ when tip of \#10 K-file (MANI Inc., Japan) became observed at the apical foramen.

ProTaper Universal rotary NiTi files (Dentsply, Maillfer, Switzerland) were used in a crown-down manner for root canal preparation with torque and speed adjusted according to manufacturers' recommendations for each file used. A set of six instruments were used, the first three files were used for coronal $2 / 3$ preparation and the other three files were used for apical preparation. After each instrument use, irrigation was done with a fresh preparation of $2 \mathrm{ml} 2.6 \% \mathrm{NaOCl}$ solution (Alex. Deteregents and Chemical Co., Egypt) for 1 minute dispensed through a 31 gauge Navi-Tip flexible irrigating needle (Navi-Tip, Ultradent product, South Jourdan, UT).

\section{Samples grouping:}

After sample preparation, the samples were divided into two main groups (I, II) according to the 
final rinse used (20 samples each) and control group (10 samples): Group I: irrigated with 17\% EDTA (Amrit Chem\& Min. Ag, Mohali, India), Group II: Samples were irrigated with Apple vinegar (Kemal Kükrer Apple Vinegar- Turkey) and Control group: Samples were irrigated with sterile saline (AlMottahedoon Pharma, Egypt).

Each main group was subdivided into two subgroups (A and B) according to the agitation file used: Subgroup A: Conventional irrigation with no agitation, where the final rinse was done using $5 \mathrm{ml}$ of each solution for 1 minute, dispensed through a 31-gauge Navi-Tip flexible irrigating needle. Subgroup B: Conventional Irrigation agitated with XP Endo Finisher, where the final rinse was done using $5 \mathrm{ml}$ of each solution agitated with XP Endo Finisher (FKG Dentaire SA, La Chaux-de-Fonds, Switzerland), where the finisher was taken from sterile packaging, placed in the handpiece and the working length was determined using plastic tube and stopper.

The XP Endo Finisher was used with 16:1 reduction handpiece that was by an electric motor; set at a rotational speed of $800 \mathrm{rpm}$ and a torque of 1 N.cm, then advanced to working length using gentle 7-8 mm lengthwise movements of insertion and withdrawal that was applied in the canal filled with final rinse for 1 minute. When XP Endo Finisher was inserted into root canal, exposed to the temperature of the body, the shape was changed depending on the A- phase. After each use, a file was cooled using ethyl alcohol spray (Medical Union Pharmaceutical, Egypt) through the plastic tube. After the final rinse, all samples were rinsed with distilled water (Ostuka pharm, Egypt) and dried by paper point.

\section{Scanning electron microscopic evaluation:}

Groove was done longitudinally on the external surfaces of each sample (buccal \&lingual) by a diamond disc, without reach the entire canal, and then carefully splitted by a chisel and mallet. The hemisected side of each tooth which contained the whole length of the root canal was selected. Sample was measured length wise by a caliper at cementoenamel junction (CEJ) to the apex to determine the three root thirds. Points corresponding to the half of the three thirds were demarcated to scan.

Root canals cleanliness and smear layer were evaluated at three root levels by SEM (FEI Company, Nertherland). Photomicrographs were taken under magnification (X 4000) for evaluation of smear layer and analyzed by means of numerical evaluation score ${ }^{(25)}$.

\section{Statistical analysis}

Data were explored for normality by checking data distribution and using Kolmogorov-Smirnov and Shapiro-Wilk tests of normality. Data were presented as mean values and standard deviation (SD). For non-parametric data; Kruskal-Wallis test was used to compare between irrigants. MannWhitney $\mathrm{U}$ test was used to compare between two irrigating techniques. Friedman's test was used to compare between root levels. Dunn's test was used for pair-wise comparisons when Kruskal-Wallis test or Friedman's test was significant. The significance level was set at $P \leq 0.05$. Statistical analysis was performed with IBM SPSS Statistics Version 20 for Windows.

\section{RESULTS}

\section{Comparison of smear layer scores between tested irrigants at each root level:}

Minimum, maximum and median of all groups will be presented in table (1). There was no statistically significant difference in the median scores of smear layer produced by $17 \%$ EDTA and Apple Vinegar at all levels when conventional irrigation or XP Endo Finisher were used. 
Table 1: Minimum, maximum and median of smear layer scores comparing the tested irrigants and control group at the all root levels by different irrigating technique

\begin{tabular}{|c|c|c|c|c|c|c|c|c|c|c|c|}
\hline \multirow{2}{*}{ 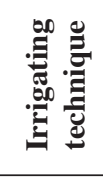 } & \multirow{2}{*}{ Root level } & \multicolumn{3}{|c|}{$\begin{array}{c}\text { Group I } \\
(17 \% \text { EDTA })\end{array}$} & \multicolumn{3}{|c|}{$\begin{array}{c}\text { Group II } \\
\text { (Apple vinegar) }\end{array}$} & \multicolumn{3}{|c|}{$\begin{array}{c}\text { Control group } \\
\text { (Saline) }\end{array}$} & \multirow{2}{*}{$P$-value } \\
\hline & & $\begin{array}{l}\text { Mini- } \\
\text { mum }\end{array}$ & $\begin{array}{c}\text { Maxi- } \\
\text { mum }\end{array}$ & Median & $\begin{array}{l}\text { Mini- } \\
\text { mum }\end{array}$ & $\begin{array}{c}\text { Maxi- } \\
\text { mum }\end{array}$ & Median & $\begin{array}{l}\text { Mini- } \\
\text { mum }\end{array}$ & $\begin{array}{c}\text { Maxi- } \\
\text { mum }\end{array}$ & Median & \\
\hline \multirow{4}{*}{ 焉 } & Coronal & 1 & 2 & $1^{\mathrm{B}}$ & 1 & 2 & $1^{\mathrm{B}}$ & 3 & 4 & $3^{\mathrm{A}}$ & $0.001^{*}$ \\
\hline & Middle & 1 & 3 & $2^{\mathrm{B}}$ & 1 & 2 & $1.5^{\text {в }}$ & 3 & 4 & $4^{\mathrm{A}}$ & $0.001^{*}$ \\
\hline & Apical & 2 & 3 & $3^{\text {в }}$ & 2 & 3 & $3^{\text {в }}$ & 4 & 5 & $5^{\mathrm{A}}$ & $<0.001 *$ \\
\hline & Total & 1.33 & 2.33 & $2^{\mathrm{B}}$ & 1.33 & 2.33 & $2^{\text {в }}$ & 3.67 & 4.33 & $4^{\mathrm{A}}$ & $0.002 *$ \\
\hline \multirow{4}{*}{ 율 } & Coronal & 1 & 2 & $1^{\mathrm{B}}$ & 1 & 2 & $1^{\text {в }}$ & 3 & 4 & $3^{\mathrm{A}}$ & $<0.001 *$ \\
\hline & Middle & 1 & 2 & $1.5^{\text {B }}$ & 1 & 2 & $1.5^{\text {в }}$ & 3 & 4 & $4^{\mathrm{A}}$ & $0.001 *$ \\
\hline & Apical & 2 & 3 & $2^{\mathrm{B}}$ & 2 & 3 & $2.5^{\text {в }}$ & 4 & 5 & $4^{\mathrm{A}}$ & $0.001 *$ \\
\hline & Total & 1.33 & 2 & $1.67^{\text {в }}$ & 1.33 & 2.33 & $1.67^{\text {в }}$ & 3.33 & 4.33 & $3.67^{\mathrm{A}}$ & $0.002 *$ \\
\hline
\end{tabular}

*: Significant at $P \leq 0.05$.

Comparison of smear layer scores between irrigating techniques within each group at each root level:

Minimum, maximum and median of all groups will be presented in table (2). There was a statistically significant difference between irrigating techniques (conventional irrigation and XP Endo Finisher file) at apical level when 17\% EDTA used as final rinse, where XP Endo Finisher file showed statistically significant lower median smear layer score $(\mathrm{P}=0.023)$. Figure $(1)$

Table 2: Minimum, maximum and median of smear layer scores comparing the different irrigating techniques at all root levels with the tested irrigants and control group.

\begin{tabular}{|c|c|c|c|c|c|c|c|c|}
\hline \multirow{2}{*}{ Irrigant } & \multirow{2}{*}{ Root level } & \multicolumn{3}{|c|}{ Conventional irrigation } & \multicolumn{3}{|c|}{ XP Endo Finisher file } & \multirow{2}{*}{$P$-value } \\
\hline & & Min & Max & Median & Min & Max & Median & \\
\hline \multirow{4}{*}{$\begin{array}{c}\text { Group I } \\
\text { (17 \% EDTA) }\end{array}$} & Coronal & 1 & 2 & 1 & 1 & 2 & 1 & 0.739 \\
\hline & Middle & 1 & 3 & 2 & 1 & 2 & 1.5 & 0.353 \\
\hline & Apical & 2 & 3 & 3 & 2 & 3 & 2 & $0.023^{*}$ \\
\hline & Total & 1.33 & 2.33 & 2 & 1.33 & 2 & 1.67 & $0.029 *$ \\
\hline \multirow{4}{*}{$\begin{array}{c}\text { Group II } \\
\text { (Apple vinegar) }\end{array}$} & Coronal & 1 & 2 & 1 & 1 & 2 & 1 & 0.690 \\
\hline & Middle & 1 & 2 & 1.5 & 1 & 2 & 1.5 & 1.000 \\
\hline & Apical & 2 & 3 & 3 & 2 & 3 & 2.5 & 0.310 \\
\hline & Total & 1.33 & 2.33 & 2 & 1.33 & 2.33 & 1.67 & 0.310 \\
\hline \multirow{4}{*}{$\begin{array}{l}\text { Control group } \\
\text { (Saline) }\end{array}$} & Coronal & 3 & 4 & 3 & 3 & 4 & 3 & 0.690 \\
\hline & Middle & 3 & 4 & 4 & 3 & 4 & 4 & 1.000 \\
\hline & Apical & 4 & 5 & 5 & 4 & 5 & 4 & 0.310 \\
\hline & Total & 3.67 & 4.33 & 4 & 3.33 & 4.33 & 3.67 & 0.310 \\
\hline
\end{tabular}

*: significant at $P \leq 0.05$. 


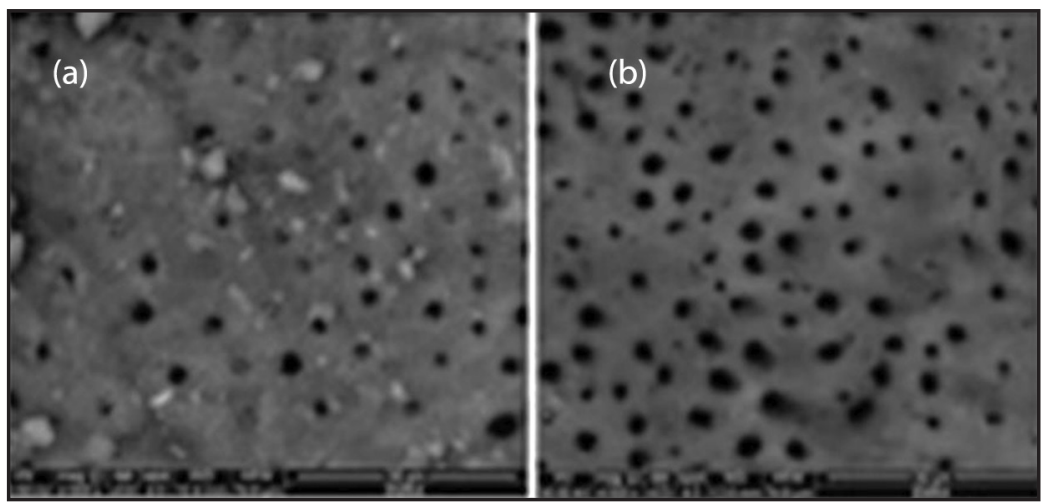

Figure (1) A scanning photomicrograph of the apical level of a root canal rinsed with $17 \%$ EDTA by conventional irrigation $(\mathrm{A})$ and $\mathrm{XP}$ Endo Finisher file (B).

With group II (Apple vinegar): At the apical level, samples treated with XP Endo Finisher file recorded lower median smear layer scores compared to that recorded with conventional irrigation. However, no statistical significant difference between the two irrigating techniques (conventional irrigation and XP Endo Finisher file) at all levels ( $\mathrm{P}=0.690,1.000$ and 0.310). Figure (2)

\section{Comparison of smear layer scores among the root levels within each group:}

The results showed that the apical level showed the statistically significantly highest median smear layer score compared to the middle and coronal levels. However, there was no statistical significant difference between the middle and coronal levels regardless the type of irrigant.

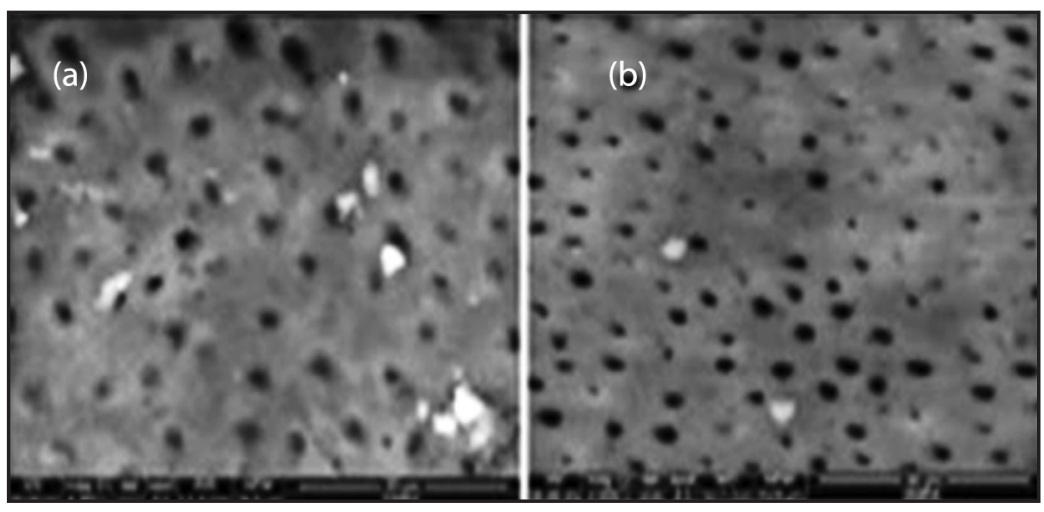

Figure (2) A scanning photomicrograph of the apical level of a root canal rinsed with Apple vinegar by conventional irrigation (A) and XP Endo Finisher file (B).

\section{DISCUSSION}

There is no irrigating solution acts simultaneously on the two component of the smear layer (organic and inorganic). Sodium Hypochlorite combined with EDTA has been used for efficient removal of smear layer ${ }^{(26-28)}$. Searching for chelating agent that is more efficient and biocompatible than EDTA has resulted in various solutions being researched over the last few years. Accordingly, apple vinegar was used in the present study due to its biocompatibility, chelating capacity, antimicrobial potential and its cost-effectiveness ${ }^{(4,6,13)}$.
A volume of $5 \mathrm{ml}$ 17\% EDTA and commercial apple vinegar was used as final rinse after irrigation with $\mathrm{NaOCl}$, for 1 minute. Since it has been reported that irrigation with $5 \mathrm{ml}$ 17\% EDTA for 1 min contact time was efficient in smear layer removal ${ }^{(29.30)}$. Similarly, it has been showed that irrigation with apple vinegar applied for 1 minute was efficient in smear layer removal ${ }^{(4,6)}$.

Irrigating needle is the most well-known method used in irrigation. It is proved that this method has less efficiency in the apical level ${ }^{(15)}$. The apical third of the curved root canal is not able to be cleaned due 
to the apical third size is small that interfere with the action of the irrigating solutions ${ }^{(15,31)}$. Therefore, XP-endo Finisher file was used in this study after final rinse to remove the debris and smear layer in root canals after biomechanical instrumentation by using SEM. Several studies have shown that $\mathrm{XP}$-endo Finisher file is powerful in smear layer removal ${ }^{(18,22)}$.

\section{Effect of irrigant on smear layer scores:}

In this study, no statistical significant difference in the median smear layer scores produced by $17 \%$ EDTA and Apple vinegar at all root canal levels.

Samples treated with Apple vinegar showed lower median smear layer score in the middle third compared to that treated with $17 \%$ EDTA. These results might be attributed to that apple vinegar has acids in its constitution, and the malic acid is the main component which is responsible for the therapeutic property of the apple vinegar ${ }^{(32)}$. These results were in agreement with previous study that reported the more efficacy of Apple vinegar to remove smear layer ${ }^{(13)}$.

The lower median smear layer score with apple vinegar reported in this study was in disagreement with previous study, which revealed that the apple vinegar was not able to clean the canal wall, with significant difference between EDTA at the coronal third. These discrepancies might be attributed to differences in the selected teeth, where they used less volume of apple vinegar $(3 \mathrm{ml})$ and less volume of $\mathrm{NaOCl}$ irrigation ${ }^{(33)}$.

\section{Effect of irrigating techniques on smear layer scores:}

Samples treated with XP Endo Finisher file recorded lower median smear layer scores compared to that recorded with conventional irrigation at the apical level regardless the type of irrigant. However, no statistically significant difference between two irrigating techniques (conventional irrigation and XP Endo Finisher file) when Apple vinegar used as final rinse.
The results of this study attributed to the specific design of XP-endo Finisher file that can reach inaccessible parts of the canal and provide better cleaning. Its Small diameter (ISO 25) and the fact that it can change its shape during rotation in the canal ( $\mathrm{M}$ and A phase) allow this file to reach inaccessible areas of the canal wall and efficiently remove dentin debris and smear layer. Due to its highly flexible proprietary without taper which with efficient irrigation in instrumented canals can remove smear layer and dentin debris from inaccessible areas ${ }^{(17)}$.

Results of this study was in agreement with previous studies reported that XP-endo Finisher file was more effective for removing smear layer in comparison to different irrigation regimens ${ }^{(18,19,24)}$.

The results of the current study showed that no statistical significant difference between the two irrigating techniques (conventional irrigation and XP Endo Finisher file) at the coronal and middle levels regardless the type of irrigant.

The results of the current study can be explained by tha easy reach of the coronal and middle thirds which have larger diameter of dentinal tubules orifices by instruments and chemical solutions ${ }^{(13)}$.

In this study, the results was in agreement with another study reported that coronal and middle thirds was less challenging for smear layer removal by XP-endo Finisher file comparing to other root canal levels ${ }^{(24)}$

\section{Effect of root level on smear layer scores:}

In this study, results showed that, there was a statistically significant difference between the all root levels in the median smear layer scores. The apical level showed the statistically significantly highest median smear layer score compared to the middle and coronal levels. However, there was no statistical significant difference between the middle and coronal levels. 
It has been reported that, coronal and middle levels have less challenge in smear layer removal in comparable with the apical level. That is due to the size of the canal in these thirds is larger than in the apical which enhance the irrigating solution efficiency ${ }^{(14)}$.

At apical level, in general, it has been proved that there was a definite decline in the efficiency of irrigating solution in the apical third. This could be due to the fact that dentin is more sclerosed in the apical level and there is reduction in root canal and dentinal tubules diameter, which impairs the access of irrigant, with consequent reduction in its flow ${ }^{(34)}$.

These results of were in agreement with other studies reported that low effectiveness of irrigants in cleaning the apical third ${ }^{(35,36)}$.

On the other hand, results of this study was in disagreement with another study reported that, EDTA produced efficient smear layer removal from all root thirds. This could be clarified by the large size of apical diameter as the canal was prepared to a size F5 ProTaper Universal file. Increase the apical size facilitates exposure of dentin to larger volumes of irrigants which improve the efficiency of the irrigant ${ }^{(37)}$.

\section{CONCLUSIONS}

1. Apple vinegar presented similar smear layer removal efficiency from intraradicular dentin compared to $17 \%$ EDTA when used as final rinse.

2. The irrigation methods may affect the smear layer removal efficiency of Apple vinegar when used as final rinse.

3. XP-Endo Finisher file is an effective root canal agitation system for smear layer removal from intraradicular dentin when using Apple vinegar or $17 \%$ EDTA as final rinse.

\section{REFERENCES}

1. Violich DR and Chandler NP. The smear layer in endodontics - A review. Int Endod J 2010; 43: 2-15.

2. Zehnder M, Kosicki D, Luder H, Sener B, Waltimo T. Tissue-dissolving capacity and antibacterial effect of buffered and unbuffered hypochlorite solutions, Oral Surg Oral Med Oral Pathol Oral Radiol Endod 2002; 94:756-62.

3. Hülsmann M, Heckendorff M, Lennon A. Chelating agents in root canal treatment: mode of action and indications for their use. Int Endod J 2003; 36: 810-30.

4. Costa D, Dalmina F, Irala LED. The use of the vinegar as a chemical auxiliary in endodontics: a literature review. Rev Sul-Bras Odontol 2009; 6: 185-93.

5. Spanó JC, Silva RG, Guedes DF, Sousa-Neto MD, Estrela C, Pécora JD. Atomic absorption spectrometry and scanning electron microscopy evaluation of concentration of calcium ions and smear layer removal with root canal chelators. J Endod 2009; 35: 727-30.

6. Zandium DL, Correa FOB, Sampaio JEC, Rossa Junior C. The influence of vinegar on exposure of dentinal tubules: a SEM evaluation. Braz Oral Res 2004; 18: 63-8.

7. Morgental R, Tanomaru JM, Júnior NB, Duarte MA, Kuga MC, Filho M. Antibacterial efficacy of endodontic irrigating solutions and their combinations in root canals contaminated with Enterococcus faecalis. Oral Surg Oral Med Oral Pathol Oral Radiol Endod. 2011; 112:396-400.

8. Estrela C, Estrela CRA, Decurcio DA, Silva JA, Bammann LL. Antimicrobial potential of ozone in an ultrasonic cleaning system against Staphylococcus aureus. Braz Dent J 2006; 17:134-8.

9. Estrela C, Lopes HP, Elias CN, Leles CR, Pécora JD. Cleanliness of the surface of the root canal by apple vinegar, sodium hypochlorite, chlorhexidine and EDTA. Rev Assoc Paul Cir Dent 2007; 61: 177-82.

10. Estrela C, Holland R, Bernabé PFE, Souza V, Estrela CRA. Antimicrobial potential of medicaments used in healing process in dogse teeth with apical peridontitis. Braz Dent J 2004; 15: 181-5.

11. Irala LED, Soares RG, Barbosa AN, Rorig A, Peter J. Capacity to remove smear layer of dentin root canal after use the vinegar of alcohol and vinegar of apple as irrigants solutions during endodontic therapy. Stomatol 2009; 15 : 47-57.

12. Spanó JC, Silva RG, Guedes DF, Sousa-Neto MD, Estrela C, Pécora JD. Atomic absorption spectrometry and 
scanning electron microscopy evaluation of concentration of calcium ions and smear layer removal with root canal chelators. J Endod 2009; 35: 727-30.

13. Candeiro GT, Matos IB, Costa CF, Fonteles CS. Vale MS. A comparative scanning electron microscopy evaluation of smear layer removal with apple vinegar and sodium hypochlorite associated with EDTA. J Appl Oral Sci 2011; 19: 639-43.

14. Safwat HA, Nour El-deen MM, Bastawy HA. Evaluation of smear layer removal and calcium ions concentration in intraradicular dentin treated with apple vinegar. Thesis submitted to the Faculty of Dental Medicine for Girls, AlAzhar University, 2017.

15. Gu LS, Kim JR, Ling J, Choi KK, Pashley DH, Tay FR. Review of contemporary irrigant agitation techniques and devices. J Endod 2009; 35: 791-804.

16. Gawdat SI, El-Asfouri H. Efficacy of xp-endo finisher, passive ultrasonic irrigation, vibringe and conventional syringe irrigation on debris removal in oval root canals: a comparative study. EDJ 2017; 63: 711-9.

17. Trope M, Debelian G. XP-3D FinisherTM file-the next step in restorative endodontics. Endod Pract US. 2015; 8: $22-4$.

18. Živković S, Nešković J, Medojević MJ, Bajić MP, Sandić MZ. XP-endo Finisher: A New Solution for Smear Layer Removal. Serb Dent J 2015; 62: 122-9.

19. Elnaghy AM, Mandorah, A, Elsaka, SE. Effectiveness of XP-endo Finisher, EndoActivator, and File agitation on debris and smear layer removal in curved root canals: a comparative study. Odontol 2017; 105:178-83.

20. Azim AA, Aksel H, Zhuang T, Mashtare T, Babu JP, Huang GT. Efficacy of 4 Irrigation Protocols in Killing Bacteria Colonized in Dentinal Tubules Examined by a Novel Confocal Laser Scanning Microscope Analysis. J Endod. 2016; 42: 928-34.

21. Leoni GB, Versiani MA, Silva-Sousa YT, Bruniera JF, Pécora JD, Sousa-Neto MD. Ex vivo evaluation of four final irrigation protocols on the removal of hard-tissue debris from the mesial root canal system of mandibular first molars. Int Endod J. 2017; 50: 398-406.

22. Azzawi MG, Mehdi JA. Cleaning Efficiency of XP-endo Finisher File in Comparison with Sonic and Ultrasonic Irrigation Systems (An In Vitro Study) J Dent Med Sci 2016; 16: 80-6.
23. Liviac D, Moldauer BI, Garcia-Godoy F, Antonio-Campos A, Casaretto M, Torres-Navarro J, Scalercio J. Comparison of the XP-Endo Finisher File System and Passive Ultrasonic Irrigation (PUI) on Smear Layer Removal after Root Canal Instrumentation. J Dent Oral Health 2017; 4: 1-7.

24. Hammad MI, Abdallah AM, Leheta NA. Cleaning Efficiency of XP-endo Finisher and EndoActivator. Alex Dent J. 2018; 43: 46-50.

25. Hülsmann M, Rümmelin C, Schäfers F. Root canal cleanliness after preparation with different endodontic handpieces and hand instrument. A comparative SEM investigation. J Endod 1997; 23:301-6.

26. Cehreli ZC, Uyanik MO, Nagas E, Tuncel B, Er N, Comert FD. A comparison of residual smear layer and erosion following different endodontic irrigation protocols tested under clinical and laboratory conditions. Acta Biomater Odontol Scand 2013; 71: 1261-6.

27. Zia A, Andrabi SM, Bey A, Kumar A, Fatima Z. Endodontic irrigant as a root conditioning agent: An in vitro scanning electron microscopic study evaluating the ability of MTAD to remove smear layer from periodontally affected root surfaces. Singapore Dent J 2014; 35:47-52.

28. Bryce G, O’Donnell D, Ready D, Ng YL, Pratten J, Gulabivala K. Contemporary root canal irrigants are able to disrupt and eradicate single- and dual-species biofilms. J Endod 2009; 35:1243-8.

29. Calt S and Serper A. Time-dependent effects of EDTA on dentin structures. J Endod 2002; 28:17-9.

30. Mello I, Robazza CR, Antoniazzi JH, Coil J. Influence of different volumes of EDTA for final rinse on smear layer removal Oral Surg Oral Med Oral Pathol Oral Radio Endod 2008; 106:40-3.

31. Mancini M, Cerroni L, Iorio L, Armellin E, Conte G, Cianconi L. Smear layer removal and canal cleanliness using different irrigation systems (EndoActivator, EndoVac, and passive ultrasonic irrigation): field emission scanning electron microscopic evaluation in an in vitro study. J Endod 2013; 39: 1456-60.

32. Caligiani A, Acquotti D, Palla G, Bocchi V. Identification And Quantification Of the main organic components of vinegars by high resolution $1 \mathrm{H} \mathrm{Nmr}$ Spectroscopy. Analyt Chim Acta 2007; 585: 110-9.

33. Rodrigues CT, Bernardineli N, Duarte MAH, Bramante CM, Andrade FB. Evaluation of EDTA, apple vinegar and Smear Clear with and without ultrasonic activation on 
smear layer removal in different root canal levels. Dental Press Endod 2013; 3: 43-8.

34. Park E, SHEN YA, Haapasalo M. Irrigation of the apical root canal. Endodontic Topics 2012; 27: 54-73.

35. Prabhu SG, Rahim N, Bhat KS, Mathew J. Comparison of removal of endodontic smear layer using sodium hypochlorite, EDTA and different concentrations of maleic acid: a SEM study. Endodontol 2003; 15: 20-5.
36. Rathakrishnan M, Sukumaran VG, Subbiya A. Efficacy of an Innovative Irrigant on Smear Layer Removal - SEM Analysis. J Clin Diagn Res 2016; 10: 104-6

37. Andrabi SM, Kumar A, Tewari RK, Mishra SK, Iftekhar H. An In Vitro SEM Study on the Effectiveness of Smear Layer Removal of Four Different Irrigations. Iran Endod J 2012; 7: 171-6. 